Orvosbiológiai, sebészeti és fogászati tudományok kar, Milánói Egyetem, Fondazione IRCCS Ca' Granda Ospedale Maggiore Policlinico, Milánó, Olaszország* Semmelweis Egyetem, FOK, Arc-, Állcsont-, Szájsebészeti és Fogászati Klinika, Budapest, Magyarország**

\title{
Az égő száj szindrómáról
}

\author{
Diagnózis és etiológia
}

DR. SPADARI FRACESCO*, DR. GARAGIOLA UMBERTO*, DR. DZSIDA ESZTER*, DR. AZZI LORENZO*, DR. KÁLMÁN FANNI SÁRA**

\begin{abstract}
A dolgozat célja az „égő száj szindrómával” (Burning Mouth Syndrome - BMS) kapcsolatos nemzetközi irodalom legfontosabb megállapításainak összegzése és áttekintése. Az eltelt évtizedek alatt számos kutató gyakorlatban és elméletben is foglalkozott ezzel a különös betegséggel. Ennek ellenére sem világos teljesen a szindróma etiológiája és pathogenezise. A szerzők az etiopathogenezissel kapcsolatos eddigi irodalmi adatokat analizálva nem találtak egyetértést sem a BMS klasszifikációja, sem a diagnózis tekintetében. Ezért egy úgynevezett „Gold Standard” osztályozást tartanak szükségesnek a betegség jobb megértése érdekében, melynek első lépéseit megtették.
\end{abstract}

Kulcsszavak: Égő száj szindróma, égő száj, nyál, szájszárazság, neuropátiás fájdalom, pszichológiai fájdalom.

\section{Bevezetés \\ (meghatározás és terminológia)}

A nemzetközi irodalom szisztematikus áttekintésével célunk az égő száj szindrómával (Burning Mouth Syndrome, BMS) kapcsolatos szempontok összegzése. Szeretnénk helyesen értékelni a betegség kórtani tényezőit, javaslatot tenni a szájüregi diszkomfort újbóli meghatározására, továbbá elemezni a betegség etiológiai tényezőit és pathogenezisét.

Az égő száj szindróma nem ritka betegség. A felnőtt, úgynevezett „normál” populációnál prevalenciája $0,7 \%$ és 15\% közöttire tehető [9]. Klinikai megjelenését tekintve változó tulajdonságokat mutat.

Van der Waal [44] olyan meghatározást adott, amely összefoglalja, egyesíti az égő száj szindróma komplex klinikai képét. Az elnevezéssel kapcsolatban sok félreértés van, így például a glossodynia vagy glossalgia fogalmak használhatók a fájdalmas nyelv leírására, de a glossopyrosis csak a nyelv égő érzését foglalja magába. Pusztán diszkomfort érzés esetén a lingualis dysaesthesia kifejezés használható. Hasonlóképpen, a nyelvet kizáró, szájüreggel kapcsolatos panaszoknál a stomatalgia, stomatopyrosis és az orális dysaesthesia fogalmak jöhetnek szóba. Múfogsort viselő betegeknél gyulladásos változások fordulhatnak elő a múfogsor alatt, különösen a felső fogsor esetében. Ezt a jelenséget „denture stomatitisnek” vagy „stomatitis protheticának” nevezik, és ennél az állapotnál a múfogsor eltávolítása után az égő érzés tünetei enyhülnek vagy teljesen megszünnek. Más esetben a múfogsort viselő betegek égő vagy viszkető érzésre panaszkodnak, klinikailag megfigyelhető gyulladásos jelek nélkül. Ez az állapot a fogsor okozta stomatitis (Denture Sore Mouth, DSM). A múfogsor eltávolítása legtöbb esetben nem eredményezi a tünetek megszúnését. Úgy tǔnik, hogy átfedés van a BMS és DSM között.

Van Joost és munkatársai [45] szerint a BMS nem a DSM szinonimája, mivel az utóbbi állapotnál igazolt ok-okozati összefüggés áll fenn a tünetek és a protézis használata között. 1988-ban Lamey és Lamb [33] olyan határozott, többtényezős etiológiával rendelkező kórképként határozta meg a BMS-t, amelynél a fizikális vizsgálat során nem található nyálkahártya rendellenesség. A szájnyálkahártya bármely területe érintett lehet, de leginkább a nyelv és a fogsort támasztó területek. Van der Waal [44] szerint a BMS kifejezés csak idiopátiás panaszok esetében használható, ahol az elsődleges tünetek, amelyeket égő, fájdalmas vagy viszkető érzésként írnak le, a szájnyálkahártyán jelentkeznek, a nyelv érintettségével vagy anélkül, vagy a test más részén társult tünetekkel vagy azok nélkül.

Jól ismert tény, hogy az égő szájra panaszkodó betegek közül sokan szájszárazságban (xerostomia) is szenvednek, amelyhez társulhat az ízérzékelés elvesztése vagy az ízérzékelés megváltozása is, melyeket együttesen BMS szindrómaként jellemeznek. Néhány szerző a BMS-t az atípusos arcfájdalom (atypical facial pain, AFP) csoportjába sorolja. Az AFP, az atípusos odontalgia és az orális dysaesthesia, beleértve a BMS-t is, előfordulhat egymás után vagy egyidejűleg ugyanannál a betegnél [14]. 
Browning és mtársai és mások $[7,48]$ is a BMS-t olyan intraorális rendellenességnek tekintették, amelyet a nyelv, az ajkak és a fogíny nyálkahártyáján jelentkező spontán égő érzés jellemez. A Nemzetközi Fájdalom Szövetség (International Association for the Study of Pain, IASP) és a Nemzetközi Fejfájás Szövetség (International Headache Society) 2004-es meghatározása szerint a BMS olyan jól körülírható kórtani fogalom, amely helyi, dentális vagy szisztémás betegség hiányában felöleli a szájban jelentkező égő érzés és panasz összes olyan formáját, amelyet csípő érzésként vagy fájdalomként írnak le, és amelynél a szájnyálkahártya klinikailag normális képet mutat [26]. Ezen túlmenően olyan fájdalomként határozta meg, amelynek időtartama legalább 4-6 hónap. A szindróma szó különösen helyénvaló, mivel a betegek az égő érzésen túlmenően gyakran panaszkodnak szájszárazságra, az ízérzékelés elvesztésére vagy megváltozására, múfogsor intoleranciára, facialis arthro-myalgiára, atípusos arcfájdalomra és atípusos odontalgiára. Sok betegnél ezek a különböző állapotok egyidejüleg vagy egymás után jelentkeznek.

Még ha nincs is széles körü egyetértés a BMS meghatározásában, az etiológia hiánya a kulcs. Az időtartam hossza, amíg a beteg az égő érzést tapasztalja, és az egymással összefüggő tünetek két újabb előfeltételt jelenthetnek a BMS egyértelmű meghatározásában.

\section{Epidemiológia}

A BMS valós előfordulását nehéz meghatározni mert a szigorú diagnosztikai kritériumok hiányoznak. Általában véve ez az állapot elsősorban a nőket érinti, körülbelül 3:1 arányban.

A nemek közötti ilyen eltérés talán biológiai, pszichológiai és/vagy szociokulturális tényezőkkel magyarázható. A szindróma ritkán jelentkezik 30 éves kor alatt, és soha nem írták még le gyerekek vagy serdülők esetén. Nincsenek tanulmányok a foglalkozás, képzettség vagy társadalmi csoportok szerinti prevalenciáról. Tammiala-Salonen és mtársai [43] tanulmányainak célja az volt, hogy meghatározza a BMS prevalenciáát egy reprezentatív mintájában. 431 egyén (237 nő és 197 férfi) vizsgálatát végezték el. Kikérdezték őket a tartósan fennálló égő érzéssel kapcsolatos tapasztalataikról, beleértve annak helyét, súlyosságát, időtartamát stb. Az összes vizsgált egyén közül $15 \%$ tapasztalt szájban jelentkező, tartósan fennálló égő érzést, de ezek felénél volt valamilyen orális nyálkahártya lézió vagy candidiasis. A panaszok előfordulása jelentősen magasabb volt nők esetén, mint férfiaknál.

Szelektáltabb populációk esetében végzett tanulmányok - pl. a menopauzában lévő betegeknél - 18-33\% előfordulást észleltek.

Ferguson és mtársai [16] vizsgálata 145 ovariectomián átesett nőből álló csoportot követett nyomon egy évig. Körülbelül a csoport felét kezelték ösztrogénpótlással, míg a többieket placebóval. Az eredmények azt mutatták, hogy az ösztrogén pótlásnak nincs közvetlen hatása a szájüregi tünetekre, de általában nélküle a szomatikus panaszok gyakoribbak lettek, amelyek korrelációt mutattak az előforduló neurózis mértékével. Wardrop és mtársai [47] tanulmányozták az orális diszkomfort és a menopauza közötti kapcsolatot 149 olyan nő esetén, akiket a kérdőívre adott válaszaik alapján három csoportba osztottak. A csoportok a következők voltak: 50 menopauza előtti nő (30-43 évesek), 47 menopauzában lévő olyan nő, aki nem kapott kezelést a menopauza során kialakult tünetekre (3766 évesek), és 52 menopauzában lévő olyan nő, akik menopauza során kezelést kaptak (30-63 évesek). Az utolsó csoport általános orvosi vizsgálaton vett részt, amely kiterjedt pszichológiai és szájüregi vizsgálatra orális kenetvétellel és tenyésztéssel, valamint vérvizsgálatokra. Az utolsó csoportban 33\% számolt be orális diszkomfortról, de nem találtak olyan nyilvánvaló organikus rendellenességet, amely e tünetet okozhatta. Az orális diszkomfort prevalenciája jelentősen magasabbnak mutatkozott a menopauzában és posztmenopauzában lévő nőknél (43\%) mint a premenopauzában lévőknél $(6 \%)$. Az eredmények az orális diszkomfort és a menopauzában lévő nők pszichológiai tünetei közötti összefüggésre is rámutattak. A menopauzában lévő, orális diszkomfortra panaszkodó nők körülbelül kétharmadánál ez a tünet rendeződött a hormonpótló terápia után. Az eredmények azt jelzik, hogy az orális diszkomfort a menopauza általános tünete, amely gyakran lép fel nyilvánvaló klinikai tünetek nélkül és gyakran rendeződik a megfelelő hormonpótló terápia során. A betegek csaknem kizárólag az idősebb korosztályhoz tartoztak; átlagéletkoruk 50-60 év [21].

Ez az eredmény egyben azt is jelezheti, hogy a nők sokkal gyakrabban keresnek egészségügyi ellátást, mint a férfiak, de ugyanakkor arra is utalhat, hogy a menopauzával kapcsolatos tényezők is szerepet játszanak az idősebb nőknél jelentkező fokozott prevalencia tekintetében.

Egy másik tanulmányban Locker és Grushka [36] más jellegű epidemiológiai adatokat mutat be. A vizsgálat célja azt volt, hogy felmérjék az ilyen típusú fájdalom prevalenciáját és mindennapi életre gyakorolt hatását. 1014 egyént választottak ki véletlenszerűen. Az érintettek $71,6 \%$-ától szereztek információt. A kérdőívek 39,7\%-a számolt be az előző négy hét során tapasztalt dentális vagy facialis fájdalomról. A tünetek aggodalom vagy nyugtalanság formájában jelentkező pszichológiai hatásáról 70,3\%-uk, míg 58,0\%-uk egy vagy több viselkedésbeli hatásról számolt be. A leggyakoribb viselkedésbeli probléma a fogorvossal vagy orvossal való konzultáció, bizonyos ételek kerülése, gyógyszerszedés és alvási zavar volt. Súlyos hatásról, például munkaképtelenségről, ágynyugalomról és csökkent társas kapcsolatokról is beszámoltak néhányan. A beszámolók szerint a fájdalom és a diszkomfort leggyakoribb 
fajtái a meleg vagy hideg folyadék okozta, fogban jelentkező fájdalom (28,8\%), az érzékeny és vérző íny $(26,3 \%)$ és a fogfájás (14,1\%) voltak. Az állkapocsban, az arcon és a szájnyálkahártyán jelentkező fájdalomról kevesebb mint 10\%-uk számolt be. A válaszadók fele a fájdalmat enyhének minősítette, de a többiek közepesen súlyos vagy súlyos fájdalmat jeleztek.

A válaszadók körülbelül 4,5\%-a „hosszasan fennálló égő érzést tapasztalt a nyelven vagy a száj más részében”. Egy későbbi utánkövető telefonos felmérés során azonban a szájban tapasztalt égő érzéses tünetekről beszámoló egyének csupán 35\%-ánál jelentkeztek a BMS egyéb tünetei. A fájdalomról beszámolók csupán 40\%-a fordult fogorvoshoz vagy orvoshoz [37]. Itt a nemek közötti különbsége kicsi volt és statisztikailag nem volt szignifikáns, bár a kor szerinti különbségek jelentősek és szignifikánsak voltak. A fiatalabb korcsoportok gyakrabban számoltak be fájdalomról és diszkomfortról, mint az idősebbek.

1989-ben a National Institute of Dental Research és National Center for Health Statistics az USA-ban felmérést végzett, amely az orofaciális fájdalom szimptómákat, köztük a BMS-t vizsgálta. 42051 háztartásból kaptak felhasználható adatokat. A válaszadók 0,8\%-a számolt be arról, hogy az elmúlt hat hónapban legalább egyszer hosszan tartó orális égő érzést tapasztalt. Ezen egyének körülbelül 69\%-ánál ez az érzés inkább epizódokban jelentkezett, mintsem folyamatosan. Csaknem 60\% állította, hogy az elmúlt hat hónapot megelőzően is tapasztalta az orális égő érzést. Így a válaszadók többsége tekinthető úgy, hogy krónikus BM fájdalma volt. Az Egyesült Államokból származó adatok arra utalnak, hogy a BMS prevalenciája kisebb, mint amiről Locker és Grushka számolt be Kanadában $(4,5 \%)$.

A Bergdahl és Bergdahl tanulmányaiban [5] az orális panaszokat és a nyálszekréciót vizsgálták 669 férfi és 758 nő esetén. Ötvenhárom személynél (3,7\%), közöttük 11 férfi $(1,6 \%)$ és 42 nő $(5,5 \%)$ esetén állapítottak meg BMS-t. Nem találtak BMS-t a 40-49 évesnél fiatalabbaknál. A 40-49 korcsoportban a prevalencia 0,7\% volt, és ez a prevalencia 3,6\%-ra nőtt az idősebb korcsoportban. Nőknél nem találtak BMS-t a legfiatalabb korcsoportban; a 30-39 éves korcsoportban azonban a prevalencia $0,6 \%$ volt, és a prevalencia $12,2 \%$-ra emelkedett a legidősebb korcsoportban.

\section{Az orális égő érzés patogenezise}

A primer BMS pathofiziológiája nem tisztázott, és az évek során viták tárgyává vált. Az etio-pathogenezis összetettnek tűnik, és a betegek többségénél valószínűleg interakciók lépnek fel a helyi, szisztémás és/vagy pszichogén tényezők között. Különös hangsúlyt kapnak a száraz száj és ízérzékelés megváltozás együttesen fennálló tünetei. A BMS pathofiziológiájában és pathogenezisében négy, kölcsönhatásban lévő tényező ját- szik szerepet: helyi környezeti tényezők, perifériás idegrendszer, központi idegrendszer és pszichoszociális tényezők.

\section{Helyi környezeti tényezők}

Vizsgálták a nyál és a helyi környezeti tényezők szerepét, beleértve a nyálmirigy diszfunkciót és a nyálkahártya megváltozott vérellátást is. Lamey és munkatársai 114 BMS betegnél tanulmányozták a stimulált parotis szekréciós rátát. Csökkent funkció igazolódott azoknál a BMS betegeknél, akik olyan égő érzés tünetet tapasztaltak, amely egész nap fennállt [34].

BMS-re vagy ízérzékelés megváltozására és/vagy xerostomiára panaszkodó 180 betegen és 90 egészséges, kor és nem szerint megfelelő kontrollszemélyen végzett vizsgálatában Hershkovich és Nagler [25] arra a következtetésre jutott, hogy a megváltozott nyál ion-összetétel okozhatja a nyálkahártya atrófiát, amelyhez orális neuropátia társulhat.

A nyál vérellátását lézer doppler áramlásmérés segítségével értékelő BMS eset-kontrollált vizsgálatban Heckmann és munkatársai [24] kimutatták, hogy az egészséges kontroll-alanyokkal összehasonlítva a BMS betegek esetében rosszabb a nyálkahártya vérellátása. Az égő száj érzés idiopátiás szenzoros zavarát, az ízérzékelés zavarokat (dysgeusia) és a száraz szájat (xerostomia) egy entitásként ismerik el, és annak az „orális szenzoros panaszok" (Oral Sensorial Complaints, OSC) nevet adták. Nem minden OSC betegnél jelentkezik azonban mindhárom tünet.

Granot és Nagler [19] 35 OSC beteget és 19 kontrollszemélyt vizsgált annak megállapítása céljából, hogy az OSC-vel hogyan függ össze az orális szenzoros percepció megváltozása, a nyáltermelés csökkenése és bizonyos egyéni jellemzők. A nyelven végzett kvantitatív szenzoros teszt (Quantitative Sensory Testing, QST) segítségével értékelték a szenzoros percepciót, és vizsgálták a hőérzékelés- és fájdalom-küszöböket, valamint a küszöb fölötti hő-fájdalom stimulus nagyságát. A nyáltermelés profil a nyál szekréciójának és összetételének elemzését foglalta magában. A személyiség jellemzőket mind az állapot, mind az alkati szorongási tesztek alapján vizsgálták. Az eredmények jelentősen megnövekedett hőérzékelési küszöböt és a tónusos hő-fájdalomra csökkent fájdalom eredményt mutattak az OSC csoportban. Egyidejüleg megfigyelték a nyálösszetétel változásait (emelkedett $\mathrm{Na}, \mathrm{K}, \mathrm{Cl}$, Ca, IgA és amiláz koncentráció), de nem volt csökkent nyálkiválasztás a betegeknél a szájszárazságos panaszok ellenére. Az összes paraméter hasonló volt az OSC betegeknél, panaszaik jellegétől függetlenül. A megemelkedett melegérzet küszöbhöz a nyál $K$ és Cl koncentrációinak magas szintje társult. Ezek a tünetek valószínúleg a regionális vékony-rost idiopátiás neuropátiának tulajdoníthatók, amely hatással van az orális érzékelésre és a nyálkiválasztásra. A nyálképzés és a pszichés személyiségi jellemzők elemzése alapján Granot és Nagler [19] azt a hipotézist állí- 
totta fel, hogy az OSC általános alapmechanizmusa a BMS betegeknél is leírt regionális neuropátiájának, ízérzékelési zavarokon és/vagy xerostomián alapul. Pekiner és mtsai [38] a nyál különböző elemeinek - beleértve a MG, Zn, Cu és citokinek (IL2, IL6) - szintjeit vizsgálták. Nem figyeltek meg statisztikailag szignifikáns eltérést a kontrollhoz képest. Ezzel ellentétben De Moura és társai [10] arról számoltak be, hogy a $\mathrm{Cl}, \mathrm{P}$ és K szintek megnövekedtek a BMS betegeknél, ami arra utal, hogy a kis molekulasúlyú nyálfehérjék és elektrolitok a BMS esetén fontosak lehetnek a pathogenezis tisztázásához, így hozzájárulhatnak annak diagnózisához és kezeléséhez. Alacsonyabb Mg szinteket figyeltek meg Kim és mtsai [30] is, azonban csak olyan betegeknél, akiknél az égő érzés a nyelvre korlátozódott (glossopyrosis), és abban a csoportban nem, amelynél az égő érzés más szájüregi régiókat is érintett (oropyrosis). A nyál Mg szintjei így esetleg felhasználhatók diagnosztikai eszközként, és segíthetik a glossopyrosis és oropyrosis közötti differenciáldiagnózist.

Kim és munkatársai [30] egyéb nyálmarkereket is vizsgáltak. Nem stimulált és stimulált teljes nyálmintákat gyújtöttek. Meghatározták a nyál kortizol, 17B-ösztradiol, progeszteron és dehidroepiandroszteron szintjeit és a ct-amiláz enzim aktivitását. A BMS-ben szenvedő betegeknél szignifikánsan magasabb szintű volt a kortizol szintje és a 17B-ösztradiol a kontrollcsoporthoz képest. Ezek az eredmények utalhatnak a hormonális egyensúly hiányára is.

A szorongás és a nyál kortizolszintjeinek értékelésekor Amenábar és mtsai [1] normál nyálszekréciót figyeltek meg, azonban a szorongás ideje alatt a nyál kortizolszintje magasabb volt, ami a BMS, a stressz és a stresszes állapot közötti korrelációra utal. Szignifikánsan és tartósan magasabb peptid és triptáz aktivitást mutattak ki a nyálban BMS betegeknél a kontrollértékekhez képest, ami a szindróma neuropátiás etiológiáját erősítette meg.

A kalcitonin gén relációs peptid (CGRP) fontos szerepet játszik a fájdalom kialakulásában, és a trigeminovaszkuláris aktiválás biológiai markereként szolgál. Ennek a markernek a nyálban lévő szintje alacsonyabbnak mutatkozott, ami arra utal, hogy trigeminus degeneráció húzódhat meg a BMS hátterében [6]. Következésképpen a nyálszekréció és -összetétel jobb megismerése a BMS esetében sok szempontból döntő fontosságú lehet.

- A szekréció csökkenése vagy megszűnése fontos tünet, amely felhasználható a diagnosztikához (BMS, illetve BM).

- Az égő érzés esetei között is differenciálni lehet a nyelv és az orális pyrosist.

- A nyál összetétele segíthet igazolni a szindróma alapmechanizmusát és így segítheti a terápiát.

- A nyálszekréció növelésének is van terápiás hatása $[50,11]$.

\section{Perifériás idegrendszer}

Az alábbiakban néhány irodalmi adatot ismertetünk az ízérzési problémákkal kapcsolatosan. Formaker és mtsai [18] szerint a dysgeusia intenzitása csökken helyi diklonin $\mathrm{HCl}$ anesztézia után. Az eredmények arra is utalnak, hogy a szájban az égő érzés esetleg a perifériás fájdalomútvonal rendellenessége miatt alakulhat ki. Formaker és Frank [17] szerint az ízérzékelési funkció tekintetében alacsonyabb intenzitási érték mutatkozott konyhasó sós és cukor édes ízére, mint a hasonló korú, ugyanolyan nemü kontrollszemélyeknél. Nem figyeltek meg azonban intenzitásbeli különbséget a citromsav (savanyú) vagy a kinin-hidroklorid (keserű) ízlelésekor. Ezek az eredmények egyeznek azzal a hipotézissel, hogy a fájdalom-útvonal aktiválása hatással lehet az ízlelési funkcióra.

Grushka és Sessle [21] csupán a hő-fájdalom toleranciában találtak eltéréseket. A fájdalomtolerancia a nyelv hegyén szignifikánsan csökkent a BMS betegeknél, nem csökkent viszont az ajak felületén, ami a perifériás és centrális idegi funkciók sajátos megváltozására utal.

Ito és mtsai [27] megfigyelték, hogy a hő fájdalomküszöb a BMS betegek esetében a nyelven szignifikánsan alacsonyabb, a fájdalom időtartama és összetettsége viszont szignifikánsan hosszabb és nagyobb volt, mint a kontrollszemélyeknél. Ez azt mutatja, hogy kapcsolat van a nyelvet érintő fájdalom és perifériás diszfunkció, és/vagy a centrális diszfunkció között. A fent említett vizsgálatban Granot és Nagler [19] rámutatott, hogy a betegeknél szignifikánsan megnövekedett a hőérzetküszöb és csökkent a fájdalompontszám a tónusos-hő fájdalomra. Ezek az adatok azt jelzik, hogy ezeknél a betegeknél nemcsak a szenzoros komponens, hanem az effektív/motivációs komponens is kifejezetten hatással volt a fájdalomérzékelésre. Érdekes összefüggés merült fel a BMS és a perifériás idegkárosodás között. A nyelv elülső kétharmadának biopsziamintáit felhasználva Lauria és mtsai [35] kimutatták, hogy a BMS betegeknél szignifikánsan alacsonyabb az epithel idegrost denzitás, mint a kontrollszemélyeknél. Az epithel és a subpapilláris idegrostok diffúz morfológiai változásokat mutattak, axonális degenerációt jelezve. Ez a vizsgálat azt mutatja, hogy a BMS összefüggésben állhat a trigeminus vékony rostos szenzoros neuropathiával.

Egy másik vizsgálat különböző alcsoportok létezését tárta fel. Femiano [15] szerint a központi idegrendszerben a fájdalomérzés és az ízérzékelés útvonalai közötti interakció miatt lehetséges, hogy a BMS és egyéb orális fájdalmak az ízérzékelő rendszer károsodásából erednek.

Felmerült a chorda tympani csökkent müködése BMS esetén. Eliav és mtsai [12] a chorda tympani és a trigeminus ideg működését hasonlították össze. Arról számoltak be, hogy a chorda tympani csökkent múködése fontos szerepet játszhat a BMS pathológiájában. Unilaterális csökkent müködés elegendő lehet a generalizált égő érzés kialakulásához az ideg által szabályozottnál nagyobb területen is. 


\section{Ingerérzékelés}

A BMS-re vonatkozó sok információ ellenére nincs egységes koncepció az égő érzés magyarázatára. Lehetséges, hogy a BMS esetén kóros eltérés van jelen az érzékelés közvetítésért felelős perifériás vagy központi idegi mechanizmusban. A fájdalom-tolerancia szignifikánsan alacsonyabb a BMS alanyoknál a nyelv hegyén, de nem találtak különbséget a hő-fájdalom toleranciánál az alsó ajaknál. Az eredmények arra utalnak, hogy a hő-fájdalom tolerancia megváltozása nem pszichogén eredetű a BMS betegek esetében, hanem a perifériás vagy központi szenzoros funkciók sajátos megváltozásán alapszik [22].

Lehetséges, hogy ezek az eredmények szöveti változásoknak tudhatók be (pl. receptor szenzitizáció). A BMS betegek eltérően észlelhetik a stimulusokat, és ezek a különbségek esetleg kimutathatók különböző tesztek segítségével is. Húsz BMS-ben szenvedő betegnél és 20 kontrollszemélynél a következő kísérletet végezték el [32]: a betegek és a kontrollszemélyek szemét bekötötték és különböző átmérőjű furatok méretét kellett értékelniük a nyelvükön úgy, hogy ujjukkal egyező furatot kellett keresniük 31 darabból álló összehasonlító furatsorozatnál statikus, majd fázisos érintéssel. Mindkét csoport túlbecsülte a $10 \mathrm{~mm}$ átmérőnél kisebb furatok méretét, de nem volt nyilvánvaló szisztematikus eltérés a $10 \mathrm{~mm}$ átmérőnél nagyobb furatok megítélésekor. Nem figyeltek meg eltérést a tárgyméret észlelésben a BMS-ben szenvedő betegek és a kontrollalanyok között.

\section{Pislogási reflex-eltérések}

A pislogási reflex (blink reflex, BR) elektromosan kiváltható a trigeminus kután idegpályák ingerlésével. Ez a reflexválasz a trigeminus szenzoros afferens idegrostokon és azok kapcsolódásain keresztül továbbítódik a trigeminus és faciális agytörzsi magba. A supraorbitális ideg elektromos stimulálásakor a reflexválasz egy a test ugyanazon oldalon lévő korai komponensből (R1i) áll, valamint ugyanazon és ellenkező oldali késői komponensekből (R2i és R2c). Ezek mindkét oldalon rögzíthetők felszíni elektródák szem körüli izmokra helyezésével. Mind az R1, mind az R2 komponens közvetítése a taktilis A $\beta$-rostokon keresztül történik [42]. Nem károsító stimulus intenzitások alkalmazásakor megjelennek a pislogási reflex nagyon késői R3i és R3c komponensei. Az R3 komponenseket valószínúleg a vékony myelinhüvelyes Aठ5 rostok közvetítik, és embereknél ezek korrelációt mutatnak az alany fájdalomérzékelésével. Elektropszichológiai pislogás-reflex tesztet használnak a reflexívet - azaz a trigeminus és faciális idegeket és azok agytörzs kapcsolatait - érintő strukturális traumák diagnosztizálásra.

Jääskeläinen és társai [28] számoltak be először a pislogás-reflex eltéréseiről. Vizsgálatuk célja a BMS lehetséges neuropátiás alapmechanizmusainak értékelése volt a trigeminus-faciális rendszer objektív elektropszichológiai vizsgálatán keresztül. A BMS betegcsoportnál statisztikailag szignifikánsan magasabb ingerlés-küszöbök mutatkoztak a BR taktil R1 komponensére a kontroll csoporttal összehasonlítva. Ezek az eredmények és más vizsgálatok [46, 2, 3] az idegrendszer krónikus BMS-ben való lehetséges pathológiai szerepét mutatják.

\section{Központi idegrendszer}

A perifériás szinten bekövetkező változások mellett olyan adatok merültek fel, amelyek a központi idegrendszer szerepét és a perifériás idegrendszerrel való interakcióját mutatják.

Grushka és mtsai [20] felvetették, hogy a BMS kapcsolatban lehet a trigeminus szenzoros és motoros komponensének együttes hiperaktivitásával. Így a chorda tympani és/vagy nyelv-garat idegek (szuperízlelők) ízérzékelésének károsodása együttesen közrejátszik az égő érzés létrejöttében. Állatkísérletek bizonyították, hogy a bazális ganglionok fontos szerepet játszanak a fájdalominformációk feldolgozásában. Jääskeläinen és mtsai [29] BMS betegeknél tanulmányozták a striatum dopamin funkcióját. Vizsgálataik szerint szignifikánsan csökkent a preszinaptikus dopaminfunkció BMS betegek bizonyos agyi struktúráiban. Az eredmények közvetlen bizonyítékkal szolgálnak a dopaminrendszernek a fájdalomban való közremüködésére [23].

Férfiakhoz képest nőknél háromszor nagyobb a migrénes fejfájás és a temporomandibularis ízületi fájdalom jelentkezésének valószínűsége. A fájdalmas epizódok gyakran kapcsolódnak a menstruációs ciklushoz. Annak megértése érdekében, hogy a hormonszint hogyan befolyásolja a fej-, arc- és szájfájdalmat, Puri és mtsai [39, 40] a fájdalommal összefüggő neuropeptidek és ösztrogén receptor alfa (ERalfa) expressziót értékelték egereknél, a természetes ivari ciklus során. Eredményeik azt mutatják, hogy a trigeminus idegekben az ösztrogénreceptorok modulálják az érző-mozgató válaszokat.

\section{Pszichoszociális tényezők}

A BMS lehetséges pszichogén okára adott első magyarázat 1920-ból ered [13], de a legújabb irodalom is nagy figyelmet fordít a lehetséges pszichogén okokra. Egyes szerzők azonban különböző kritériumokat alkalmaztak a BMS etiológiájában a nem szomatikus ok fennállásának megállapítására. Zegarelli és mtsai [49] vizsgálataik alapján azt állították, hogy az égő száj pszichogén eredetü.

A BMS nem egységes meghatározása Zegarelli esetében is félrevezető volt. Vizsgálataiban a pszichogén kiváltó okra visszavezethető betegség diagnózisát azután állították fel, hogy minden egyéb helyi betegség lehetőségét kizárták a negatív klinikai előzmények, negatív laboratóriumi eredmények és az emocionális tényezők pozitív előzményei alapján. Néhány beteg kór- 
előzményében pszichiátriai betegség szerepelt, míg mások kórelőzményében olyan betegségek szerepeltek, amelyeket gyakran stressz okozott vagy stresszel álltak összefüggésben, azaz gyomorfekély, irritabilis vastagbél és magas vérnyomás. Így a pszichogén ok miatti BMS-ben szenvedők százalékos arányát kritikusan kell vizsgálni.

A személyiségi jellemzőket vizsgálták rezisztens BMSben szenvedő betegeknél, és azokat összehasonlították a nem és kor szerint egyező kontrollcsoporttal [4]. A BM tünetek értékelése után meghatározták a személyiségjegyeket, a pszichológiai funkciót és az életminőséget a Karolinska személyiségi skála (Karolinska Scales of Personality, KSP), egy másik személyiségi skála (Personality Scale, PS), a pszichológiai funkció skála (Psychological Functioning Scale, PFS) és az életminőség skála (Quality of Life Scale, QLS) segítségével. A kontrollcsoporttal összehasonlítva a rezisztens BMS-ben szenvedő betegek szignifikánsan alacsonyabb értékeket értek el a szocializációs skálán és szignifikánsan magasabb értéket a szomatikus szorongás, izomfeszültség skálákon. Ezenkívül a rezisztens BMS-ben szenvedő betegek szignifikánsan könnyebben merültek ki, érzékenyebbek voltak és jobban aggódtak az egészségükkel kapcsolatban. A pszichológiai funkció tekintetében a BMS betegek szignifikánsan több problémával küzdöttek a kezdeményezőkészség terén, könnyebben szédültek meg, és több szomorú gondolattal küszködtek. Gyakrabban számoltak be heves szívdobogásról és emésztési zavarokról. A megfigyelt szignifikáns különbségek a személyiségben és a pszichológiai funkcióban esetleg azt mutathatják, hogy az égő érzés pszichoszomatikus tünet. A BMS az említett szerzők szerint egy komplex zavar olyan jellemzőkkel, amelyek gyakoriak a krónikus fájdalom-állapotban szenvedőknél: gyermekkori testi és lelki trauma, depresszió, szorongás, cancerofóbia, gyomor-bélrendszeri zavarok és krónikus kimerültség [31, 8].

A pszichológiai rendellenességekről, például szorongásról és depresszióról, vagy személyiségzavarokról gyakrabban számoltak be a BMS betegeknél, mint a kontrollcsoportnál. Schoenberg [41] szerint a BMS a depreszszió tünete, pszichológiai stressz eredménye.

Összefoglalva: a BMS betegek sajátos pszichológiai és/vagy pszichiátriai profilt mutatnak, de nem ismerjük az ok-okozati összefüggést.

\section{Következtetés}

A BMS krónikus orofaciális fájdalmat jelent, amelyhez nem társulnak nyálkahártya léziók vagy egyéb nyilvánvaló klinikai jelek. A szindróma elsősorban középkorú betegeknél és menopauzában lévő nőknél figyelhető meg. A BMS jellemzője az intenzív égő vagy szúró érzés, amely tipikusan a nyelven vagy a szájnyálkahártya egyéb területein jelentkezik. Társulhat hozzá egyéb szenzoros rendellenesség, például száraz száj vagy az ízérzékelés megváltozása. Eredete valószínűleg több tényezőre vezethető vissza és gyakran idiopátiás, jelenleg még ismeretlen etiopathogenezissel lokális, szisztémás és pszichológiai tényezők egyaránt szerepet játszhatnak. Jelenleg nincs teljes egyetértés a BMS diagnózisa és osztályozása terén.

Fel kellene állítani a diagnózis és pathogenezis szempontjából egy úgynevezett „Gold Standard” klasszifikációs szisztémát, mellyel jobban lehetne körülhatárolni ezt a kórképet. Ennek érdekében további vizsgálatokra lenne szükség.

\section{Irodalom}

1. Amenábar JM, Pawlowski J, Hilgert JB, et al: Anxiety and salivary cortisol levels in patients with burning mouth syndrome: casecontrol study. Oral Surg Oral Med Oral Pathol Oral Radiol Endod 2008; 105, 460-465.

2. Beneng K, Renton T, Yilmaz Z, et al: Sodium channel Na v $1.7 \mathrm{im}$ munoreactivity in painful human dental pulp and burning mouth syndrome. BMC Neuroscience 2010; 11, 71.

3. Beneng K, Yilmaz Z, Yiangou Y, et al: Sensory purinergic receptor $\mathrm{P} 2 \times 3$ is elevated in burning mouth syndrome. Int $\mathrm{J}$ Oral Maxillofac Surg 2010; 39, 815-819.

4. Bergdahl J, Anneroth G, Perris H: Personality characteristics of patients with resistant burning mouth syndrome. Acta Odontol Scand 1995; 53, 7-11.

5. Bergdahl M, Bergdahl J: Burning mouth syndrome: prevalence and associated factors. J Oral Pathol Med 1999; 28, 350-354.

6. Borelli V, Marchioli A, Di Taranto R, et al: Neuropeptides in saliva of subjects with burning mouth syndrome: a pilot study. Oral Dis 2010; 16, 365-374.

7. Browning S, Hislop S, Scully C, ET al: The association between burning mouth syndrome and psychological disorders. Oral Surg Oral Med Oral Pathol 1987; 64, 171-174.

8. Carlson CR, Miller CS, Reid KI: Psychosocial profiles of patients with burning mouth syndrome. J Orofac Pain 2000; 14, 59-64.

9. ChaRleston L $4^{\mathrm{TH}}$ : Burning mouth syndrome: a review of recent literature. Curr Pain Headache Rep 2013; 17, 336-351.

10. de Moura SA, de Sousa JM, Lima DF, et aL: Burning mouth syndrome (BMS): sialometric and sialochemical analysis and salivary protein profile. Gerodontology 2007; 24, 173-176.

11. de Souza FT, Amaral TM, dos Santos TP, et al: Burning mouth syndrome: a therapeutic approach involving mechanical salivary stimulation. Headache 2012; 52, 1026-1034.

12. Eliav E, Kamran B, Schaham R, et al: Evidence of chorda tympani dysfunction in patients with burning mouth syndrome. J Am Dent Assoc 2007; 138, 628-633.

13. Engman MF: Burning tongue. Arch Dermatol Syphil 1920; 1, 137138.

14. Feinmann $C$, Harris M: Psychogenic facial pain. Part 1. The clinical presentation. Br Dent J 1984; 156, 165-168.

15. FEMIANO F: Damage to taste system and oral pain: burning mouth syndrome. Minerva Stomatol 2004; 53, 471-478.

16. Ferguson MM, Carter J, Boyle P, et al: Oral complaints related to climacteric symptoms in oöphorectomized women. $J R$ Soc Med $1981 \mathrm{Jul} ;$ 74(7): 492-498.

17. Formaker BK, Frank ME: Taste function in patients with oral burning. Chem Senses 2000; 25, 575-581.

18. Formaker BK, Mott AE, Frank ME: The effects of topical anesthesia on oral burning in burning mouth syndrome. Ann N Y Acad Sci 1998; 855, 776-780.

19. Granot M, Nagler RM: Association between regional idiopathic neuropathy and salivary involvement as the possible mechanism for oral sensory complaints. J Pain 2005; 6, 581-587. 
20. GrushKa M, Epstein JB, Gorsky M: Burning mouth syndrome and other oral sensory disorders: a unifying hypothesis. Pain Res Manag 2003; 8, 133-135.

21. GrushKa M, Sessle BJ: Burning mouth syndrome: A historical review. Clin J Pain., 1987; 2, 245-252.

22. GrushKa M, Sessle BJ, Howley TP: Psychophysical assessment of tactile pain and thermal sensory functions in burning mouth syndrome. Pain., 1987; 28, 169-184.

23. Hagelberg N, Forssell H, Rinne JO, et al: Striatal dopamine D1 and D2 receptors in burning mouth syndrome. Pain 2003; 101, 149-154.

24. Heckmann SM, Heckmann JG, Hilz MJ, et al: Oral mucosal blood flow in patients with burning mouth syndrome. Pain 2001; 90, 281-286.

25. Hershrovich O, Nagler RM: Biochemical analysis of saliva and taste acuity evaluation in patients with burning mouth syndrome, xerostomia and/or gustatory disturbances. Arch Oral Biol 2004; $49,515-522$.

26. International Association for the Study of Pain, Subcommittee on Taxonomy: Classification of chronic pain: descriptions of chronic pain syndromes and definitions of pain terms. Pain 1986; suppl. 3.

27. Iто M, Kurita K, Ito T, Arao M: Pain threshold and pain recovery after experimental stimulation in patients with burning mouth syndrome. Psychiatry Clin Neurosci 2002; 56, 161-168.

28. JäÄSKELÄINEN SK, ForSSELl H, Tenovuo O: Abnormalities of the blink reflex in burning mouth syndrome. Pain 1997; 73, 455-460.

29. JäÄSKELÄInen SK, Rinne JO, Forssell H, ET AL: Role of the dopaminergic system in chronic pain - a fluorodopa-PET study. Pain 2001; 90, 257-260.

30. KIM HI, KIM YY, ChANG J, ET AL: Salivary cortisol, 17ß-estradiol, progesterone, dehydroepiandrosterone, and $\alpha$-amylase in patients with burning mouth syndrome. Oral Dis 2012; 18: 613-620.

31. LAmey PJ, Freeman R, Eddie SA, et aL: Vulnerability and presenting symptoms in burning mouth syndrome. Oral Surg Oral Med Oral Pathol Oral Radiol Endod 2005; 99, 48-54.

32. Lamey PJ, Hobson RS, Orchardson R: Perception of stimulus size in patients with burning mouth syndrome. J Oral Pathol Med 1996; 25, 420-423.

33. LAMEY PJ, LAMB AB: Prospective study of aetiological factors in burning mouth syndrome. Br Med J (Clin Res Ed) 1988; 296(6631), 1243-1246.

34. Lamey PJ, Murray BM, Eddie SA, et al: The secretion of parotid saliva as stimulated by $10 \%$ citric acid is not related to precipitat- ing factors in burning mouth syndrome. J Oral Pathol Med 2001; 30, 121-124.

35. Lauria G, Majorana A, Borgna M, et al: Trigeminal small-fiber sensory neuropathy causes burning mouth syndrome. Pain 2005; 115, 332-337.

36. Locker D, GrushKa M: Prevalence of oral and facial pain and discomfort: preliminary results of a mail survey. Community Dent Oral Epidemiol 1987; 15, 169-172.

37. LoCker D, GrushKa M: The impact of dental and facial pain. J Dent Res 1987; 66, 1414-1417.

38. Pekiner FN, Gümrü B, Demirel GY, et al: Burning mouth syndrome and saliva: detection of salivary trace elements and cytokines. J Oral Pathol Med 2009; 38, 269-275.

39. PuRI V, CUI L, LIVERMAN CS, ET AL: Ovarian steroids regulate neuropeptides in the trigeminal ganglion. Neuropeptides 2005; 39, 409-417.

40. Puri V, Puri S, Svojanovsky SR, ET al: Effects of oestrogen on trigeminal ganglia in culture: implications for hormonal effects on migraine. Cephalalgia 2006; 26, 33-42.

41. SCHOENBERG B: Psychogenic aspects of the burning mouth. $N Y$ State Dent J 1967; 33, 467-473.

42. SHAHANI BT, Young RR: Human orbicularis oculi reflexes. Neurology 1972; 22, 149-154.

43. Tammiala-Salonen T, Hitdenkari T, Parvinen T: Burning mouth in a Finnish adult population. Community Dent Oral Epidemiol 1993; 21, 67-71.

44. VAN DER WAAL I: The burning Mouth Syndrome. $1^{\text {st }}$ Edition, Copenhagen, 1990.

45. VAN Joost T, VAN ULSEN J, VAN LoON LA: Contact allergy to denture materials in the burning mouth syndrome. Contact Dermatitis 1988; 18, 97-99.

46. Wagner IV, LANGe E: Zur Frage der psychischen Disposition bei Glossalgie- und Stomatodynie-Patienten. ZWR 1984; 93, 216218.

47. Wardrop RW, Hailes J, Burger H, Reade PC: Oral discomfort at menopause. Oral Surg Oral Med Oral Pathol 1989; 67, 535-540.

48. ZAKRZEWSKA JM: The burning mouth syndrome remain an enigma. Pain 1995; 62, 253-257.

49. Zegarelui DJ: Burning mouth: an analysis of 57 patients. Oral Surg, Oral Med, Oral Pathol 1984; 58, 34-38.

50. Zidverc-Trajkovic J, Stanimirovic D, Obrenovic R, et al: Calcitonin gene-related peptide levels in saliva of patients with burning mouth syndrome. J Oral Pathol Med 2009; 38, 29-33.

\section{Spadari F, Garagiola U, Dzsida E, Azzı L, Kálmán FS}

\section{Burning oral sensation: when is really BMS?}

The aims and purposes of this systematic review of the international literature are to discuss and clarify some considerations on Burning Mouth Syndrome (BMS). Over the last 40 years, many researchers have addressed this disease clinically or experimentally. Thus, the etiology and pathogenesis of BMS remain unclear. We analyzed the etiopathogenesis of Burning Mouth Syndrome and of the burning oral sensation and currently, we could not find a consensus on the diagnosis and classification of BMS. Further studies are required to better understand the pathogenesis of BMS, and a "Gold Standard" classification is required because not every burning sensation int he mouth is BMS.

Keywords: Burning Mouth Syndrome, saliva, xerostomia, neuropathic pain, psychological pain 